\title{
CHARACTERIZATION OF CATTLE SLAUGHTERED AT THE PUBLIC ABATTOIR IN LAVRAS-MG ${ }^{1}$
}

\author{
Caracterização dos bovinos abatidos no matadouro municipal de Lavras-MG
}

\author{
Adriano de Souza Guimarães², José Camisão de Souza ${ }^{3}$, Ivo Francisco de Andrade \\ Rilke Tadeu Fonseca de Freitas ${ }^{4}$, Marcelo Ângelo Cirillo ${ }^{5}$
}

\begin{abstract}
RESUMO
Com esse trabalho, objetivou-se caracterizar os bovinos abatidos no município de Lavras - MG. No matadouro municipal, foram identificados 720 bovinos, abatidos durante o período de 20 de setembro a 20 de novembro de 2004, observando-se as seguintes variáveis: origem genética, peso vivo, condição corporal, idade e sexo. Após o desembarque os animais foram pesados em balança mecânica e classificados quanto à raça e/ou grupamento genético. Antes do abate, determinou-se a condição corporal (CC), escala de 1 a 9. A condição reprodutiva foi observada durante a esfola e evisceração: macho castrado, MC; macho não castrado, MI; fêmea gestante, FG e fêmea não gestante, FNG. A idade foi determinada por visualização direta da mandíbula, através da contagem dos dentes incisivos permanentes (d.i.p.). Observou-se maior frequiência de machos abatidos no período do estudo, tendo o grupamento genético Girolando, maior frequiência. O peso médio de abate \pm desvio padrão, para machos e fêmeas $(\mathrm{n}=720)$, foi de $438,5 \pm 114,0 \mathrm{Kg}$. As fêmeas (FG e FNG), apresentaram maiores idades de abate (> 48 meses), comparadas aos machos. As FNG apresentaram menores escores de condição corporal (3,4 e 5). Os machos (MC e MI) apresentaram boa condição corporal no momento do abate. A maioria dos bovinos abatidos em Lavras foi caracterizada como sendo animais de origem genética não especializada, para a produção de carne.
\end{abstract}

Termos para indexação: Gado de corte, abate, características zootécnicas.

\section{ABSTRACT}

The objective was to characterize cattle slaughtered from the region of Lavras - MG. In the public abattoir 720 bovines were identified and slaughtered from September $20^{\text {th }}$ through November $20^{\text {th }}$ of 2004 . Variables such as: genetic origin, live weight, body condition, age, and sex were studied. At arrival, animals were weighed and classified according to their genetic origin. Before slaughter, their body condition (BC) was determined on a 1 - 9 scale. Reproductive status was observed during scratch and evisceration: castrated male, MC; intact male, MI; pregnant female, FG; and Non-pregnant female, FNG. Age was determined by the count of the permanent incisive teeth (p.i.t.). Most animals slaughtered during the survey were male, with predominance of the Girolando genetic group. Overall mean slaughter weight was $438.5 \pm 115.97 \mathrm{Kg}(\mathrm{n}=720)$. Females (FG and FNG) were older (>48 months old) as compared to male animals, FNG had lower body condition scores (3, 4 and 5). Male (MC and MI), had good body condition scores. Most of slaughtered cattle in Lavras were characterized as non-specialized for beef production.

Index terms: Beef cattle, slaughter, animal traits.

(Received in march 9, 2006 and approved in february 5, 2007)

\section{INTRODUCTION}

Beef cattle production, in Brazil, is developed in various regions of the coutry under various soil, climate, vegetation, breeds, regional management practices and technologies. The activity has been growing yearly, spreading throughout regiões, up to this time, with little beef production tradition. Biological, economical, political and technical aspects interact as determinig causes in this scenario.

The county of Lavras is located in the southern region of the state of Minas Gerais, a traditional state dairy region. Deactivation of specialized dairy herds has been observed lately in the region (FAZENDEIRO..., 1996), an the areas, used for milk production before, converting to crops such as corn, coffee and beans, dual purpose cattle raising, or even purebred beef breed operations.

There is predominance of animals of the Gir and Holstein breeds and their crosses, and there are also Holsteins, Brown Swiss, Jersey and other Zebu breed crosses. The herd has been improving, despite local observations indicating a dairy herd reduction, and a

\footnotetext{
${ }^{1}$ Extraído da Dissertação de Mestrado apresentada pelo primeiro autor à Universidade Federal de Lavras.

${ }^{2}$ Mestre - Centro Tecnológico do Norte de Minas/CTNM - Empresa de pesquisa Agropecuária de Minas Gerais/EPAMIG - Cx. P. 12 - $39.525-000$ - Nova Porteirinha, MG - adriano.guimaraes@epamig.br

${ }^{3}$ Ph.D, Professor - Departamento de Zootecnia/DZO - Universidade Federal de Lavras/UFLA - Cx. P. 3037-37200-000-Lavras, MG - jcamisao@ufla.br, iandrade@ufla.br

${ }^{4}$ Doutor - Departamento de Zootecnia/DZO - Universidade Federal de Lavras/UFLA - Cx. P. 3037 - 37200-000 - Lavras, MG - rilke@ufla.br

${ }_{5}^{5}$ Doutor-Departamento de Ciências Exatas/DEX - Universidade Federal de Lavras/UFLA-Cx. P. 3037-37200-000-Lavras, MG-marcelocirillo@hotmail.com
} 
concomitant increment of beef herds. There is however, still a clear predominance of dairy activity, encompassing $79.6 \%$ of the herd, according to the last census (SEBRAEMG, 1998). The State governmental census (Censo Agropecuário de Minas Gerais 1995-1996) registered 29093 heads of cattle in the county (IBGE, 1996). Additional literature data, characterizing the cattle herd in the county of Lavras are very scarce.

The objective was to characterize the cattle slaughtered in the City of Lavras Abattoir, through the evaluation of exterior and carcass characteristics.

\section{MATERIALAND METHODS}

The work was conducted at the Alves \& Fagundes City Abattoir, located at the fourteenth kilometer of BR 265 road, in Lavras, MG. Data were collected from $20^{\text {th }}$ of September to $20^{\text {th }}$ of November of 2004. A total of 720 cattle were examined, representing $16.6 \%$ of all animals slaughtered in 2004.

Animals were readily identified at arrival and unloading at the abattoir and various characteristics recorded such as hide color, horns, particular brandings and finally paint marked with each owner previously established number. All data were collected in field forms so that they could be identified after slaughter.

Breeds and genetic groups were determined by direct observation of exterior characteristics. The following genetic groups were defined, according to Santos (1999): Nelore, Gir, Tabapuã, Marchigiana, Red Angus, Holstein, Jersey, Brown Swiss, Canchin, Caracu, Simmental and Girolando. All animal resembling Zebu and Holstein, but not entirely falling into any of the previous groups, were assigned as Crossbreds.

Live body weight was determined through individual weighing, at abattoir arrival without previous fasting, on a mechanical scale.

Body condition scores (BCS) were assigned before slaughtering according to Dias (1991), by three trained individuals, independently. Means from these scores were used.

Age was determined by direct lower jaw visualization of the permanent incisive teeth (p.i.t.), according to Jardim (2005): 0 p.i.t. - up to 18 months old; 2 p.i.t.- 18 to 24 months old; 4 p.i.t.- 24 to 36 months old; 6 p.i.t. 36 to 48 months old and p.i.t. above 48 months old.

Gender and reproductive status, (pregnant - FG; non-pregnant - FNG; castrated - MC and intact MI - males), were determined after slaughter.

Descriptive statistical techniques were used to determine percentages and means for the type characteristics observed. Moreover, for gender versus weight, age versus gender and BCS versus gender, multivariate techniques were used, through simple correspondence analyses, according to Greenacre (1993).

\section{RESULTS AND DISCUSSION}

In this study the frequency of slaughtered males was $57.2 \%$, which differs with results in a report by Lima (2002) in which a greater proportion of slaughtered females in Lavras, from 01 and 31st of March 2001. This difference may possibly be explained by the period during which the present study was done, September and November, when, normally, prices paid to the producers tend to be better, compared to that of other months and by the greater market values of males (ANUALPEC, 2004).

Because the region is traditionally a dairy region, the county of Lavras presents an expressive offer of animals originating from dairy and/or dual purpose herds to be slaughtered, which was observed in the present study (table 1).

There are indications that the utilization of male diary calves, may contribute to a substantial proportion of the national cattle raising economy (TIESENHAUSEN et al, 1980). This can be seen in reports showing the great percentage of dairy originated animals slaughtered in abattoirs.

The low percentage $(5.0 \%)$ of specialized beef breeds suggests, that, producers from Lavras, do not, yet, raise specialized beef animals, significantly. In this aspect, it may also be that some specialized herds do exist, but finished animals are slaughtered elsewhere.

In conclusion the analysis of the main components on the gender versus weights contingency table (table 2), denominated by main coordinates (MINGOTI, 2005), allows the identification of similar groups, and association of weight classes with the observed gender (Figure 1).

Results from table 2 indicate that the two components explain $100.0 \%$ of the total variability of the total frequencies, related to the genders classified by weights. This finding allows the analysis of the proportions (line and column) by a bi-dimensional graphic, called perceptual map (Figure 1).

According to the illustrations by means of circles, on Figure 1, gender and weight classes are associated. The same rationale was applied for the age versus BCS.

Pregnant females and castrated males are associated to the intermediary weight class $(360-540 \mathrm{Kg})$. Intact males are associated to the highest weight class $(>540 \mathrm{Kg}$ ). Possibly, the weight superiority of the intact males compared to that of other classes it is an effect of testosterone. (CARDOSO, 1996; SAINZ, 1996). Overall 
mean weight and standard deviation found in this study $(\mathrm{n}=720)$, was $438.6 \pm 116.0 \mathrm{Kg}$, ranging from 208.0 to 920.0 $\mathrm{Kg}$. Extreme slaughter weights are undesirable, slowing down the slaughtering process mainly by not adapting to the physical structure of the plant and the carcass are usually disproportionate.
Main components analyses for the age and gender contingency table (table 3), allows the association of these two variables since they explain $98.85 \%$ of the total frequency variability related to age classified by gender.

Associations between gender and age are shown in figure 2.

Table 1 - Frequency of bovines slaughtered in Lavras, according to their specialization for meat roduction.

\begin{tabular}{ccc}
\hline Genetic groups & Number of animals slaughtered & \% of total \\
\hline Specialization & 3 & 0.4 \\
\hline Canchim & 6 & 0.8 \\
Marchigiana & 23 & 3.3 \\
Nelore & 1 & 0.1 \\
Red Angus & 3 & 0.4 \\
Tabapuã & 36 & 5.0 \\
Sub-total & & 7.5 \\
\hline Non specialized & 54 & 1.3 \\
Holstein & 9 & 0.4 \\
Jersey & 3 & 9.2 \\
Brown Swiss & 66 & 17.2 \\
Sub-total & & 0.3 \\
\hline Mixed or dual purpose & 124 & 3.2 \\
Zebu cross & 2 & 38.0 \\
Caracu & 23 & 15.1 \\
Gir & 274 & 11.6 \\
Girolando & 109 & 0.4 \\
Holstein cross & 83 & 85.8 \\
Crossbreds & 3 & 100.0 \\
Simmental & 618 & \\
Sub-total & 720 & \\
Total & & 0.0 \\
\hline & & \\
\hline
\end{tabular}

Table 2 - Analysis of main components shown on the gender versus weights contingency table.

\begin{tabular}{cccc}
\hline $\begin{array}{c}\text { Main } \\
\text { Coordinates }\end{array}$ & Variability & Proportion & $\begin{array}{c}\text { Cumulative } \\
\text { Proportion }\end{array}$ \\
\hline 1 & 0.0659 & 0.7867 & 0.7867 \\
2 & 0.0179 & 0.2133 & 1.0000 \\
\hline Total & 0.0838 & & \\
\hline
\end{tabular}

Table 3 - Main components analyses for the age versus gender contingency table.

\begin{tabular}{|c|c|c|c|}
\hline Main Coordinates & Variability & Proportion & Cumulative Proportion \\
\hline 1 & 0.2641 & 0.9307 & 0.9307 \\
\hline 2 & 0.0164 & 0.0578 & 0.9885 \\
\hline 3 & 0.0033 & 0.0115 & 1.0000 \\
\hline Total & 0.2837 & & \\
\hline
\end{tabular}




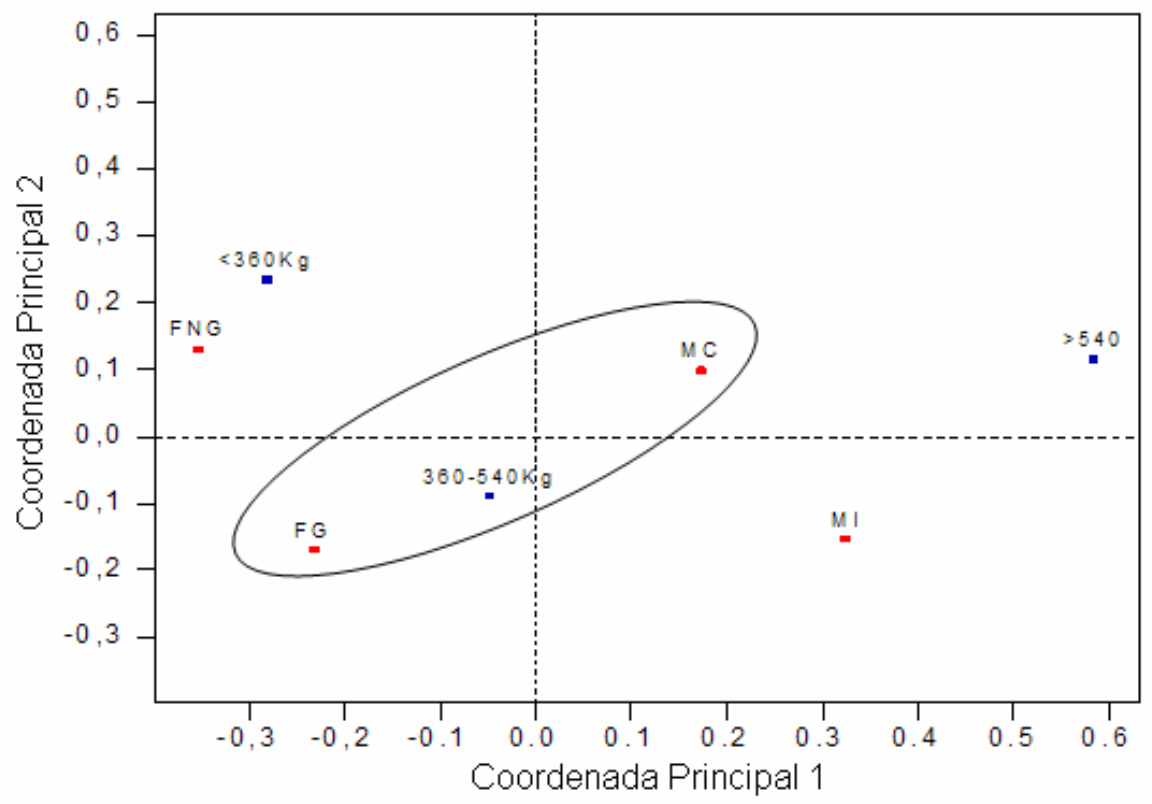

- FG - pregnant female; FNG - non pregnant female; MC - castrated male; MI - intact male

- Weight classes, in live body weight

Figure 1 - Perceptual map of gender versus weights.

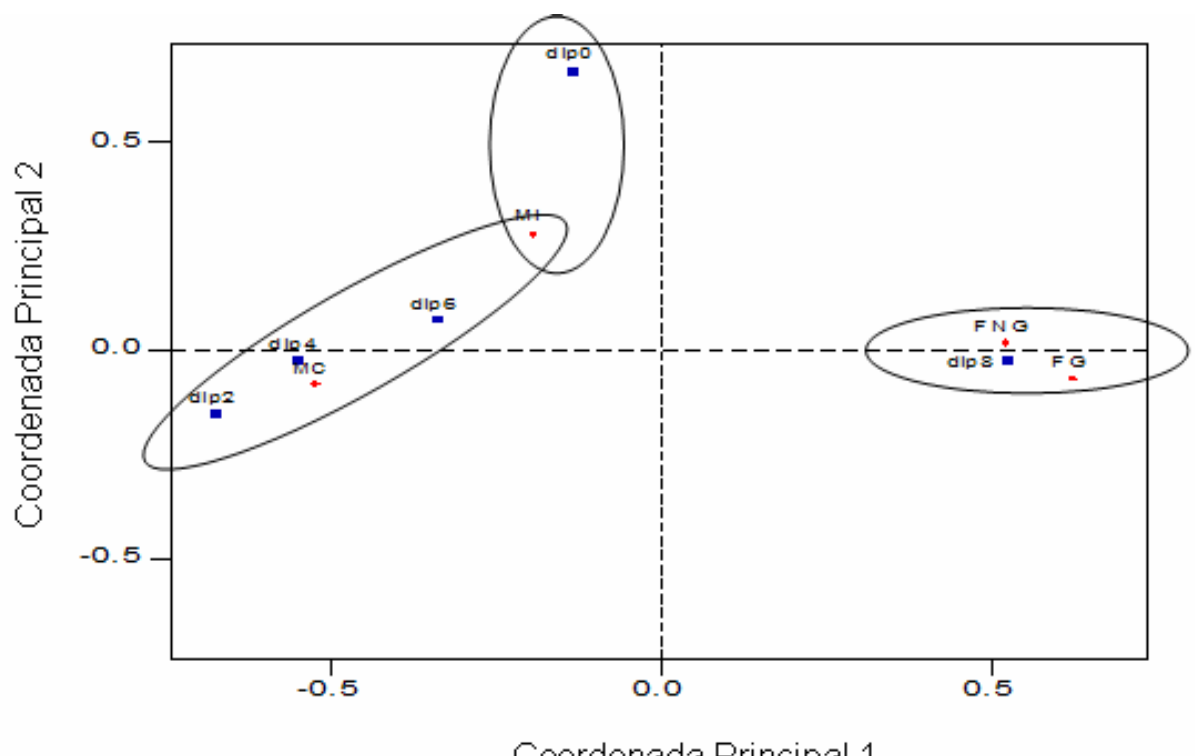

Coordenada Principal 1

- FG - pregnant female; FNG - non pregnant female; $\mathrm{MC}$ - castrated male; $\mathrm{MI}$ - intact male

a dip0 - 0 permanent incisive teeth; dip $2-2$ permanent incisive teeth; dip4 - 4 permanent incisive teeth; dip6 - 6 permanen1 incisive teeth; dip $8-8$ permanent incisive teeth

Figure 2 - Perceptual age versus gender map.

Ciênc. agrotec., Lavras, v. 32, n. 1, p. 251-257, jan./fev., 2008 
Results on figure 2 indicate that pregnant and non pregnant females were associated to the older age category, that is, above 48 months (p.i.t. 8). This association may be explained by the fact that, most females slaughtered at the county abattoir, are culled from dairy herds and these finding are similar to those reported by Silva et al. (2004).

Castrated males were associated to the ages between 18 and 48 months (p.i.t. 2, 4 and 6). This association suggests a tendency for improvements on husbandry practices by a few isolated producers, although a profile of younger age for intact males was also observed. Intact males probably had, at slaughter, undesirable carcass finishing traits, represented mainly by insufficient subcutaneous fat. In this study, the most frequent slaughter age class observed was that of 48 months (p.i.t. 8), representing $47.8 \%$ of the total animals slaughtered. The importance of age at slaughter lies mainly on aspects related to finishing and meat tenderness (BOLEMAN et al., 1996).

Main components analyses for the BCS versus gender contingency table, allows the graphic representation of a two-dimensional graph since these two components explain $94.9 \%$ of the total frequency variability related to BCS categorized by gender (table 4).

The association between BCS and gender is shown on Figure 3.

Table 4 -Main component analyses for the BCS versus gender contingency table.

\begin{tabular}{cccc}
\hline Main Coordinates & Variability & Proportion & Cumulative Proportion \\
\hline 1 & 0.1059 & 0.7620 & 0.7620 \\
2 & 0.0260 & 0.1874 & 0.9494 \\
3 & 0.0070 & 0.0506 & 1.0000 \\
\hline Total & 0.1390 & & \\
\hline
\end{tabular}

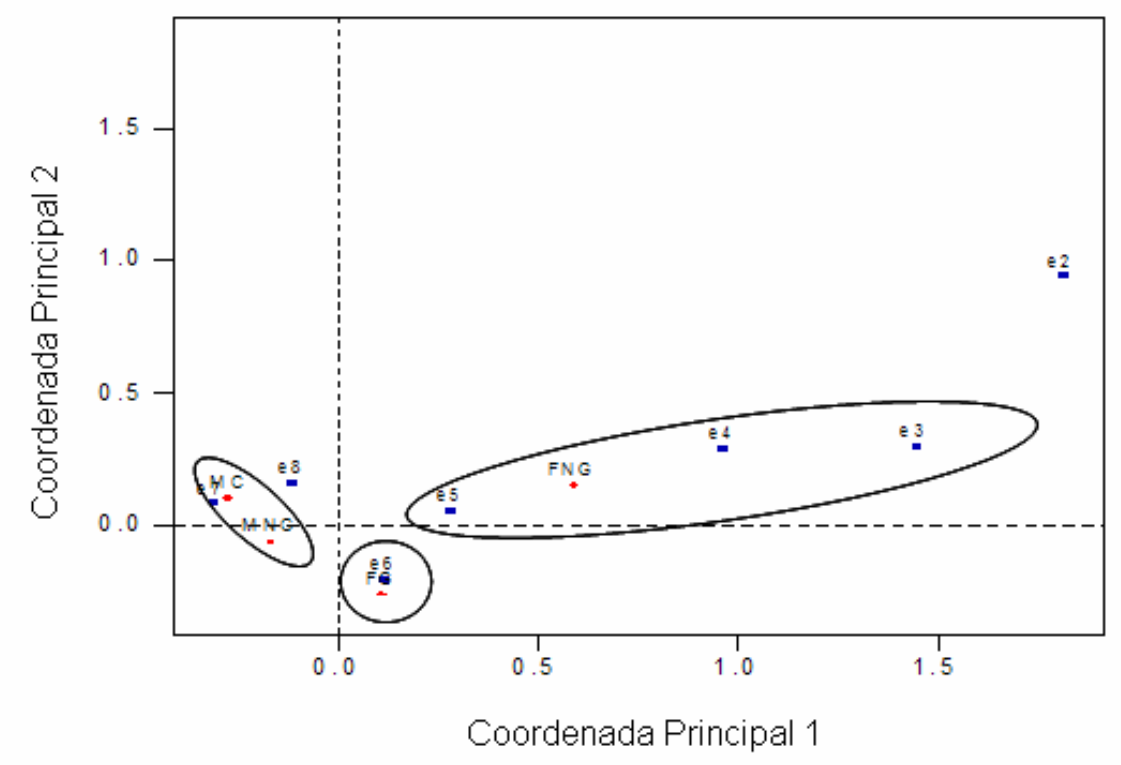

- FG - pregnant female; FNG - non pregnant female; MC - castrated male; $\mathrm{MI}$ - intact male.

- 2 to e 8 - BCS from 2 to 8 , respectively

Figure 3 - Perceptual map for BCS versus gender. 
Non pregnant females were associated to a profile or lower (3, 4 and 5) BCS (figure 3). This demonstrates that producers are careless in preparing females for slaughtering which may have been also reproductive culls. Normally non pregnancy is a decisive factor in decision making in terms of culling in herds. Lima (2002) suggests that strategies should aim body condition improvement before slaughtering.

Compared to non pregnant females, pregnant females showed better condition scores. Possibly, the action of placental hormones contributes to this fact during the initial third of gestation (GRASSI \& MÜLLER, 1991).

Males, intact and castrated, were associated to a BCS of 7. There is a tendency for better husbandry practices directed to males, by some county producers, since they have higher market values.

\section{CONCLUSIONS}

The majority of slaughtered bovines slaughtered in Lavras, $95.0 \%$ were characterized as from breeds and/or genetic groups non specialized for beef production.

Butchered males were associated to higher body condition scores than females. Castrated males and non pregnant females had similar weights at slaughter and intact males were associated to the highest weight class.

Overall results indicate that the main component analysis method supplies a good vision of the data allowing a better understanding of the possible relationships among the variables studied.

\section{ACKNOWLEDGEMENTS}

To the Minas Gerais State Research Support Foundation. - FAPEMIG, for the financial support for this study. To Fagundes e Alves- for opening the abattoir facilities for this study.

\section{REFERENCES}

ANUALPEC. Anuário da pecuária brasileira. São Paulo: FNP Consultoria \& Comércio, 2004. 376 p.

BOLEMAN, S. J.; MILLER, R. K.; BUYCK, M. J.; CROSS, H. R.; SAVELL, J. W. Influence of realimentation of mature cows on maturity, color, collagen solubility and sensory characteristics. Journal of Animal Science, Champaign, v. 74, n. 9, p. 2187-2194, Sept. 1996.

CARDOSO, E. G. Engorda de bovinos em confinamento: aspectos gerais. Campo Grande: Embrapa/CNPGC, 1996.

DIAS, F. M. G. N. Efeito da condição corporal, razão peso/ altura e peso vivo sobre o desempenho reprodutivo pósparto de vacas de corte zebuínas. 1991. Dissertação (Mestrado em Zootecnia) - Universidade Federal de Minas Gerais, Belo Horizonte, 1991.

FAZENDEIRO de Minas oferta 500 animais. Folha de São Paulo, São Paulo, 24 jul. 1996. Agrofolha, p. 8, c. 1-2.

GRASSI, C.; MÜLLER, L. Efeito do manejo de vacas de descarte no desempenho e características de vacas de descarte. Pesquisa Agropecuária Brasileira, Brasília, v. 26, n. 8, p. 1175-1181, ago. 1991

GREENACRE, M. Correspondence analysis in practice. New York: Academic Press, 1993.

INSTITUTO BRASILEIRO DE GEOGRAFIA E ESTATÍSTICA. Censo agropecuário 1995-1996. 1996. Disponível em: <http://www.ibge.gov.br>. Acesso em: 15 mar. 2005.

JARDIM, W. R. Avaliação da idade pelo exame dos dentes. Uberaba: ABCG, 2005. Disponível em: <http:// ww w.girolando.com.br/site/arqdown/ idade_pelos_dentes.pdf>. Acesso em: 16 nov. 2005.

LIMA, I. de A. Condição corporal e características de carcaça de vacas de descarte na região de Lavras - MG. 2002. 67 p. Dissertação (Mestrado em Zootecnia) Universidade Federal de Lavras, Lavras, 2002.

MINGOTI, S. A. Análise de dados através de métodos de estatística multivariada: uma abordagem aplicada. Belo Horizonte: UFMG, 2005. 295 p.

SAINZ, R. D. Qualidade das carcaças e da carne bovina. In: CONGRESSO BRASILEIRO DAS RAÇAS ZEBUÍNAS, 2., 1996, Uberaba. Anais... Uberaba: ABCZ, 1996. Não paginado.

SANTOS, R. dos. Os cruzamentos na pecuária tropical. Uberaba: Agropecuária Tropical, 1999. 672 p.

SEBRAE-MG. Lavras: diagnóstico municipal. Belo Horizonte, 1998. 179 p.

SILVA, L. A. F.; SILVA, E. B.; SILVA, L. M. Causas de descarte de fêmeas bovinas leiteiras adultas. Revista Brasileira de Saúde e Produção Animal, Salvador, v. 5, n. 1, p. 9-17, 2004. 
TIESENHAUSEN, I. M. E. V. von; AZEVEDO, N. A.; produção de carne. Informe Agropecuário, Belo Horizonte, REHFELD, O. Aproveitamento do macho leiteiro para $\quad$ v. 6, n. 69, p. 34-37, set. 1980. 